\title{
To Bryllupper -
}

et i Skrydstrup $1685 \mathrm{og}$ et i Senderballe 1686.

Af Pastor emer. M. H. Nielsen.

\section{Paa Bryllupsgaarden i Skrydstrup.}

Lordag den 18. Oktober 1685 holdtes der Bryllup hos Gaardmand Thomas Tjellesen i Skrydstrup.') Navnet paa Brud og Brudgom nævies ikke, men det maa vist have været sit eget Bryllup, han fejrede. Det omtales nemlig som "Thomas Tjellesens Bryllup«. Og det har vel varet et Bryllup, som Bryllupper var flest paa den Tid. De strakte sig gerne over flere Dage. Sjælden blev der sparet paa Maden, som Gæsterne selv for ell stor Del havde sørget for ved at sende Smør, Eg, Fjerkrax, Skinke o. s. v. til Bryllupsgaarden. Drikkevarer blev (ler ogsaa jævnlig nydt rigeligt af, undertiden mere end goult var. Det var som ved andre festlige Lejligheder - navnlig GIlet, det gik ud over.

Mange Grster synes der ogsaa at have været med ved Thomas Tjellesens Bryllup. De fleste var vel nok fra sognets

- Hovedby, Skrydstrup, men der var ogsaa Folk fra tlldal og fra Horlyk. Enkelte udensogns Gaster var der ogsaa. Allerede her skal vi næune enkelte af Crasterne ved Navn.

Der er forst Sognets Prest, Hr. Mathias. Hans fulde Navn er Mathias Thomsen schinck. Han var Fynbo, barneforlt i Odense. Inden han blev Sogneprast i skrydstrup, havde han været Kapellan hos sin Forgænger i Embedet, Hans Pedersen, der syrnes at være død først paa Aaret 1669. Maaske har han været gift med en Datter af Hans Pedersen. I et skifte efter denne, dateret 3. l'ebr. 1669, siges det, at "den salige Mands Livsklæder, som ikkun vare saare ringe, ere sønderskaaren og gjort hans Datters Son Klieder af og Enken et Skjørt." Det er muligt, at denne Datter har været gift med Kapellanen. Rot længe kan Egteskabet i saa Fald ikke have varet, idet han 1675 bliver gift med en Datter af den tidligere Borgmester Lauritz 
Knudsen i Haderslev. Hun hed Birgitte.") Han var Præst her til sin Dod 1704. I) to sidste Aar havde han vistnok sin Efterfolger, Peder Rasmussen Als, som Medhjaelper. ${ }^{3}$ ) I sin Beskrivelse af Haderslev Amt fra 1775 siger P. Rhode om ham, at han var "velstuderet og havde Rigdom«. Paa sidstnæevnte Punkt var han en Modsxtning baade til sin Forgænger og sin Efterfolger.

Saa er der Sognets Degn Johan Degn, som han altid kaldes i Tingbogen. Hans fulde Navn var Johan Hansen, og han var (iaardmand i skrydstrup.3n) I Tingbogen navnes han allerede 1669 i det ontalte skifte efter Hans Pedersen. Der staar heri, at Johan Degn har \& Mark tilgorle for "begge Begravelser. ${ }^{3 h}$ Endvidere horer vi, at den fattige Prest, der har Kreditorer spredt omkring $i$ alle Verdenshjørner, før sin Død har foraret Deguen sine støvler og sko -- „for han tjente hannem i sit yderste«. Det tyder paa et godt Forhold mellem de to, vel ogsaa paa, at Johan Degn har været en tjenstvillig Mand. I samme Retning tyder vist ogsaa det, vi ellers horer on ham. En kort Overgang or Forholdet mellem ham og hans Bysbarm Niels Christensen dog mindre godt. En Dag i lugust 1680 har de i Skrydstrup Kro vekslet »tvistige Ord《 med hinanden. Det ender med Proces. Ved et Mode for Øvrighedlen kommer det dog suart til Forlig. Begge Parter betaler i l'xllesskab Gebyret til Øvrigheden. Niels Christensen, der maa have varet den mest skyldige, skal alene »staa for kongelige Brøder «. Hermed skal "al Kiv og Trætte" mellem de to vare "ophævet, dosd og magtesiøs«. Skulde nogen af dem bryde Freden, forpligter llan sig paa Forliaand til at betale $10 \mathrm{Rd}$. i Borle til Kongen.

Endelig navner vi som Gaxster ved Brylluppet Gaardmand Peder Lassen i Skrydstrup og Aftægtsmand Peder Horlyk i Horlyk. De to var svogre. og det er dem, der bliver Hoved. personer i det, som her skal berettes. Den førstnævinte synes af Natur at have varet noget hidsig og haardhændet. For faa Aar siden havde hans Fader, Las Jørgensen, for Retten ført Klage over, at sonnen havde overfaldet ham smed Slag«. Ogsaa her kommer det til Forlig "formedelst Godtfolks Forbon o" 
Mellemhandling ". Faderen "rækker Hand til sil Søn og eftergiver hannem ..., hvorpaa Sønnen bad strax sin Fader om Forladelse og udlover efterdags at ville leve ærlige og vel imod sine Forældre

Man var paa Bryllupsdagen naaet hen »ad Aften«. Johan Degn har, som han selv siger, "faaet Brud og Brudgom til Seng ". Det havde i tidligere Tid været Skik, at alle Gæsternè fulgte Brudgom og Brud til Sengs i Brudekammeret. Præsten holdt her en Tale til Brudeparret, der blev sunget Sange eller Salmer, og Brudeparret knælede ned i Bøn foran Brudesengen, inden de betraadte denne. ") Det er sikkert nok en Rest af denne gamle Skik, vi her staar over for. Muligt er det vel ogsaa, at andre end Degnen har taget Del i denne Følgen til Sengs. Saa meget er imidlertid vist, at der ikke kom ret megen Glade ud af dette Foretagende, for Brud og Brudgom stod snart efter op af Sengen. Grunden hertil er sikkert den, at der blev Ustyr blandt Gasterme, og at nogle af dem kom ind i Brudekammeret.

Først kom Peder Hørlyk. Han havde bedt sin Svigersøn, Hans Persen i Uldal, følge med derind: "Der vilde de sidde og drikke en Kande $\emptyset 1$ sammen med Ro.« Sønnen Niels følger efter og siger til sin Fader: "Vil I følges med ind i Salen?" Men denne svarer: "Nej, her vil jeg blive siddende, her er saa roligt at sidde. - Derefter sender Præsten Bud til Peder Horlyk med Bøn om, at han vilde komme ind i Piselen og sidde der sammen med ham. "Gik han da endelig ud og satte sig hos Præsten, Hr. Mattis, i Brudesalen«.

Snart efter bryder Præsten op fra Gildet og begiver sig hjem. Ved et Landemode i Odense 1560 var der taget den Bestemmelse, at Præster skulde tage bort fra Bryllupper senest "ved ni Slæt«. $\left.{ }^{5}\right)$ Pastor Schinck har maaske kendt dette Paabud derovre fra sin Fødeø og draget sig det til Minde. I hvert Fald har han følt, at det nu for hans Vedkommende vilde være passende at afbryde Legen.

Da Prasten "er hjemgaaen«, vaagner der atter hos Peder Horlyk en stor Lyst til at forlade Piselen for sammen med sin 
Svigerson at gaa ind i Brudekammeret, hvor de vilde sidde sammen i Ro og nyde en Kande $\emptyset l$. Med den saa hojt attraaede Ro blev det dog kun saa som saa. Der fulgte nemlig snart flere efter, saaledes den fornævite Gaardmand Peder Lassen i skrydstrup. De to Svogre komner snart i Ordstrid, og ret lange varer det ikke, fur strinlen gaar over til Haandgribeligheder, idet Peder Horlyk giver sin Svoger nen under Oret«. En behjertet Mand, Peiler Christensen fra Uldal, siger til Peder Lassen: "Forliges nu vel sammen med hverandre, du og Peder Horlyk, efterdi I er Svogre og Venner«. Det gode haad fanclt dog ikke Ørenlyd. Peder Lassen siger til sin Svoger: "Hvorfor slaar I mig, der skal fare en Djavel udi eder". Og "fore de saa sammen og grebe hverandre i Haaret."

$\mathrm{Nu}$ optræeder Johan Degn som Fredsstifter. Ham havde Karen Horlyks, Peter Horlyks Hustru, opsugt inde i Brudesalen, hvor han sad, og bedt ham, om "ḥan vilde komme og stỵre noget til Retter. Forelobig lykkedes det ham at faa Peder Lassen med sig ind i Piselen eller Brudesalen, og han beder ham om at blive her. Det vil Peder Lassen dog ikke. "Vil I have, at jeg skal staa og lade mig slaa«, spørger han, slaar i Bordet og siger: "Jeg er Karl for mig, de skal faa en Ulykke«. Saa slider han sig fra Johan Degn og vil ind i Brudekammeret igen. Hans Kones Søstre, Bodel Peders og Merete Hanses, stiller sig mellem Doren og ham, men han sled dem shver til sin (Sicle) og stolte Doren op. Straks efter blev der Raaben i Kammeret." De stridende har paany faaet hinanden i Haaret, Lyset vælter ned af Bordet og slukkes. I Morket har Peder Horlyk faaet sin Kniv frem, og ned den stikker han sin Modstander.

Inde i Piselen faar Johan Degn nu tandt et Lys, og med det i Haanden vil han gaa ind i Brudekammeret. I Doren moder han Peder Lassen, der siger: "Han stak migu. Paa Spørgsmaal om, hvem der havde stukket ham, svarer han blot: "Nu lar jeg faaet nok.« Saa synker han dod om paa Gulvet.

Da Hans Jørgensen fra Uldal lidt efter kom ind i Brudekammeret, saa han, at Vinduet var »udstødt«, og han fik den 
"Formening, at Folkene der var inde, maatte have gaaet derud af."

\section{Fra Gram Herreds Ting.}

Scenen forlixgges nu fra Bryllupsgaarden til Gram Herreds Ting. Hvor laa saa det? Uvilkaarlig soger man mod vest tif det Sogn, der har givet Herredet Navil. Men Gram Sogn og Gods var blevet udskilt fra let svrige Herred og havde faaet sin egen Retskreds. Ii maa vende vort Blik i modsat Retning. Lidt ost for skrydstrup By begyuder der en gammel Vej, som nu om Dage er grumme lidt befærdet. Den kaldes Tingvejen. Ad den er Sognets Beboere gaaet i gamle Dage, naar de skulde til Tings ved Tørning i Nabosognet Hammelev. Hvor lange Tingstedet har været her, kan nxppe siges, men flere Ting viser, at det i hvert Fald fandtes her, da det ontalte Drab skete. Oprindelig er 'Tinget sikkert ogsaa her holdt under aaben Himmel. Men ret tidlig har man faaet brgget et Tinghus til Skærm mod Kulde og ondt Vejr. I 1676 hører vi om, at 'Tinghuset trænger til heparation, wefter som det ganske er forfalden«. Herredsfogden spørger de paa Tinget forsanlede sognefogder, hvad de vilde "resolvere" on en saadan Reparation. Hertil svarede de "santlige«, at de begrerede "Opsættelse, til Gud vil, at de store skatter, som er paabudet, maatte forlindres." Saa "vilde de nok dertil give, hvad Ret var. "') Helt ungt kan det forfaldne Tinghus jo næppe have været. Antagelig har det ligget paa det Sted, hvor det laa et Hundrede Aar senere: øst for Vejen mellem Torning Mølle og Tørning Kro, ud for det Sted, livor Udløbet fra Stevuing Dam begynder, ${ }^{7}$ ) Her mødtes flere Veje og stier fra Hammelev og omliggende sogne.

Til bedre Forstadelse af det efterfolgende skal forudskikkes nogle Bemarkninger om Rettens Gang ved Herredstinget. sarlig om de Personer, der tog Del i Rettens Pleje her. Det var ikke saa helt faa. Paa den Tid er der i Gran Herred to "kongelige Fogder" Herredsfogden og Ridefogden. Den gamle Herredsfoged, Gaardmand Jep Andersen i Bæk, Nustrup Sogn var - som Indskriften paa hans Gravsten i Nustrup Kirke viser 
-. dod 24. April 1670. Forst paa Aaret 1671 stoler vi i Tingbogen paa den nye Herredsfoged: Peder Hansen Holm, der samme Aar kober Fastegaarden Selskar i Jegerup Sogll. Sidst i Halvfjerdserne maa han vistıok paa Grund af en Strid med nogle af Sognets Bonder fratrode sit Emberle. I August Maaned 1680 bliver den sforrige Herredsfoged" dog atter indsat til "fremdeles som tilforn" at forvalte Retten i Gram Herrerl. Samne Aar sælger han Gaarden i Jegerup. En Tid synes han at have boet i Hadersilev. Ved sin Dod omkring ved Aaret $1705^{\circ}$ var han vistuok som sine uærmeste Efterfolgere - Forpagter paa den kongelige Avlsgaard Torning i Hammeler Sogn.") Ridefogden i Gram Herred hed paa den Tid Nicolas eller Nicolai Rye. Han boede vistnok hele Tiden i Haderslev, hvor hall 1707 valges til Borgmester, men knap en Maaned senere bliver han afsat.") .En Herreds- eller Tingskriver besørgede det skriftlige Arbejle ved Tinget.

Foruden de her navite Mand var der tre Grupper af Mand, hver Gruppe paa 8 Medlemmer, der havde en Gerning at rogte paa Herredstinget. Forst maa navnes de 8 sandenæand, en slags Navninge eller Dommere. $\left.{ }^{10}\right)$ De afgav Kendelse (svor) eller dømte i flere forskellige sager saasom Manddrab, Harvark, (Vold), Markeskel og Volitægt. De skulde bo spredt over hele Herredet to $i$ hver Fjerding. Inden de tiltrader stillingen, skal de aflagge Ed paa, at de ikke i deres Enbede vil gore andet end sdet retteste og det sandester. I selve Orint Sandemand ligger der vel ogsaa en Antyduing af, at vedkommende maatte hore til de "bedste og sandestea Mandi." ) Men selv om Sandemændene blev tagne mellem Egnens fremmeligste og mest ansete Mrend, hander det dog. at en og anden af lem ikke magter at skrive sit fulı Navn, men maa nøjes med som Underskrift at sxte nogle faa Bogstaver eller et Bomarke. For deres ['lejlighed kunde de gore Krav paa "Hesteleje« eller Rejsegodtgørelse. Sandemandsembedet var livsvarigt, hvis da vedkommende ikke selv forbrød sig mod Loven. Denne Bestemmelse er maaske senele hen ikke holdt saa noje." I (iram Herred er der dog tilsymeladende ringe skiften. 
I Tiden fra 1661 til 70 gaar der kun een Mand ud. To af Mændene fra 1661 fungerer endnu 25 Aar efter. Blandt de afgaaede synes to at være afløste af Sønner. Mellem 1670 og 1680 bliver Peder Hørlyk udnæevnt til Sandemand. Den forste Tingdag i Aaret 1681 faar han og en anden Sandemand overdraget det Hverv nat forsegle $i$ dette Aar». Det Hverv at forsegle de paa Tinget udstedte Dokumenter synes at være gaaet paa Omgang mellem Sandemændene. Havde Herredsfogden Forfald, eller han var Part i den Sag, der var til Behandling, traadte en af Sandemændene i hans sted som Vicefoged. Et Par Gange optræder Peder Hørlyk som Tingholder eller stedfortrædende Herredsfoged. Det var saaledes Tilfældet den sidste Tingdag i Aaret 1684 .

Foruden Sandemændene var der 8 Ransnavninge. Ofte kaldes de ogsaa blot Navninge. De domte i Sager vedrørende aabenlys Krænkelse af Ejendomsretten. Deres Funktionstid var kun et Aar. Den forste Tingdag efter Nytaar blev de indsat i Embedet efter at være edfæstede. Dette Ting var sarlig betydningsfuldt. Det blev i den største Del af Sønderjylland kaldt Allemandstinget, $i$ den storste Del af Norrejylland Snapstinget og i Ribeegnen Driktinget. De tre Navne antyder vel, at Aarets forste Tingdag var særlig godt besogt, og at der paa den Dag blev drukket en Del. Sidstnævnte Betegnelse synes iøvrigt en Tid at have været brugt $i$ de fleste nordslesvigske Herreder. $\left.{ }^{13}\right)$ Gram Herreds Tingbog for 1674 begyuder med Ordene: I Jesu Navn. Neden under staar der: Dricke 'Ting. Ogsaa det følgende Aar bruges Ordet Drikketing.

Endelig inaa vi navne de 8 Tinghørere, der fungerede som Retsvidner. De kaldes ogsaa Tinghøringsmænd, Ottemænd eller Stokkemænd. Det sidste Navn hidrorer fra, at de havde deres Plads indenfor eller paa de 4 Stokke, der onsluttede 'Tingstedet. Deres Funktionstid strækker sig kun over een Dag. De moder da frem fra hele Herredet, som Regel flest fra de Sogne, hvorfra der den Dag er Sager til Behandling. Fra flere Herreder horer vi on, at det kunde knibe med at faa Tinghørerne til at give Møde og med at faa dem til at vente, til Retsmødet var 
sluttet. $\left.{ }^{14}\right)$ Samme Vanskelighed har vel ogsaa gjort sig gaeldende i Gram Herred. Det er da rimeligt, at man fortrinsvis har taget Tinghørerne blandt de nærmest boende. Særlig paafaldende er det, saa hyppigt 'Tingstedets narmeste Naboer, Kromanden og Mulleren i Torning, optræder som Stokkemand. ${ }^{15}$ ) Ogsaa heri har vi et Vidnesbyrd om, at Tinget paa den Tid holdtes $i$ Tørning.

Lardag var 'Tingdag for Gram Herred. Men det var ikke hver Lordag, der holdtes Ting. Det hænder ogsaa, at ler er tastsat en Tingdag, men Tinget bliver ikke holdt, da kun ottemanclene har givet Molle. I 1685 er der kun 19 Tingdage, og der er Aar, hvor Tallet er endıu lavere. - Drabet i Skrydstrup fandt jo Sted Sondag den 18. Oktober. Den følgende Tingdag borer helt igemnem Præg af dette Drab. Forst hører vi om, at Herredsfogden "1., 2. og 3. Gang opraabte«, om der var nogen tilstede med Fuldmagt fra den drabtes Euke eller Arvinger. Da der ingen melder sig, konstituerer Ridefogden "ex officio" (paa Embeds Vegne) Nis Iversen, Fredsted, som Eftermaalsmand, eller som den, der skulde "paatage sig“ den døles Say og clen til "Endskab prosequere (forfolge), saa vidt Lov og Ret er«. Det var nemlig gældende Ret, at den enkelte - ikke det offentlige - maatte paatale de Retsbrud, der blev begaaet imod ham. Det var Eftermaalsmandens Opgave at tage sig af den sag. I Almindelighed er det en af den paagaldendes nærmeste Slagt, der fik det Hverv. Nis Iversen fremkom nu forst med en Klage, hvori det hedder, at Peler Lassen er wefter Formening uskjellig dræbt«. Dernæst begærer han, at de seks Mænd fra Skrydstrup, der om Mandagen sammen med en Sandemand "efter Befaling« har været tilstede i Thomas Tjellesens Gaari for at foretage Syn over den dræbte, her "for 'Ting og Ret« edelig skal bevidne det af dem foretagne Syn. Efter aflagt Ed bevidner da de seks Mand, at de har "sýnet og beset den ihjelstukne og befunden, at han var ved den hojre Bryst over Patten indstukken, og er Saaret ungefehr af halvanden Fingers Brede. Og laa han enduu inde i Piselen .... De fandt hverken brun eller blaa, ej heller nogen videre Saar paa hannem«. 
- Saa begarer Nis Iversell, at Folk, som har varet tilstede, nda Gerningeu skete«, skal indstævnes for Retten som Vidner. Det sker de folgende Tingdage, og det er de for Retten aflagte Vidnesbyrd, vi foran har gengivet Hovedindholdet af. Endelig begærer han, at ogsaa Sandemændene maa blive indstævuede. De skal være tilstede ved Fremførelsen af Vidnesbyrdene og senere traffe Kjendelse i sagen.

Den 15. December 1685 - sidste Tingdag det $\Lambda$ ar - bliver Peder Horlyks Skmbue beseglet. De otte Sandemand er da forsamlede paa Tinget for at "tye ${ }^{16}$ ) og sværge i Drabssagen fra skrydstrup. Herredsfogden »tilfinder" eller "tildømmer"« dem nu nderom at gjore deres $\mathrm{Ed}$ og Toug $^{17}$ ) saaledes, at Kongen sker Ret og Bonden ingen Uret.« I den afgivne Kendelse maa Sandemændene indrømme, at Peder Lassen har mpinget efter det onde" hos sin Modpart. Hans Ord »le skal faa en Ilykke" viser, at han "nok som har haft i Sinde at hande eller gjøre Llykke». Men meget mere er der at bebrejde Peder Horlyk. Da Peder Lassen paany opsngte ham i Bruclekammeret, har han "ikke det ringeste Ord talet«, hverken sagt, at han ikke vilde have nogen Klammeri med Peder Lassen eller nogen anden, "langt mindre sit sæde endtviget (undveget) til at ville fly Peder Lassen og gange sin Vej af Kammeret med Fredr. Ej heller havde han "haft saar eller Hug eller var nød til at verie sit eget Liv efter Loven«. Peder Lassen var jo ikke kommen ind i Kammeret mmed vabende Hand eller med nogle dodelige Gevehre som enten Kniv, Kaare pller Wxe." Kjendelsen ender med de Ord: "Tho (da) ved vi ikke herudi rettere at kjende og domme, at som Peder Hørlyk, der for samme Sag er bortromt og (ijerningen paa sig taget, jo haver drabt sageslus Mand, og er fordi (derfor) skyldig sin Fred at miste, og det saa sandt hjelpe os Gud og hans hellige Ord."

Saa var Peder Horlyk da erklaret fredlos, og de Kaar, der ventede en saadan, var ikke just blide. $\left.{ }^{18}\right)$ Den fredlose var saa at sige udstødt af Sanfundet. Efter faa Dages Forlub oprindelig »inden Dag og Maaned«, senere efter Forlobet af tre Dogn - skulde han forlarle Kongens Riger og Lande. Det gjaldt 
baade Kongeriget og Hertugdommerne. Efter Rommingsfristens Udlob maatte ingen huse ham eller tage sig af ham. En Tid havie det endog været tillarlt at slaa ham ihjel. Denne 'Tilladelse havile i swerlig (irad galdt den drabtes Slagtninge/Blothævil). Vi horte foran, at Pe(ler Horlyk var rommet, inden han mistede sin Fred. Det er rimeligvis sket straks efter Irabet. Saadan bar de fleste Drabsminend sig ad, idet de overlod til Slangt eller Vemmer at tage sig af deres Sag.

Det var lige for Jul, Peder Horlyk blev svoret fredlos. It det ikke har varet mogen saplig lys Jul for ham derude i det fremmede eller for hans Familie derhjemme, kan vi nok forstaa. Henimod slutuingen af Januar faar Karen Horlyk Bessg af hegge de kongelige l'ogder, Herredsfogden og Ridefogiten, samt af 6 Mand fra Skrydstrup sogn. De skal vurdere det mringe Gods og Losmre«, der tilhorer hende og hendes Mand neftersom hans Hovedlod for begangen Manddrab er til kongelig Majestat forfalden«. Fredloshed drog, som vi ser, ogsaa skonomiske Folger efter sig. Fortegnelsen over Egteparrets Ejendele ser saaledes ul:

„Forst Zle Kjor, som de gamle var lagt til Aftagt, agtet for

4. Faar à $1 \mathrm{Mk}$.

2 sikp. Mynt Roug à 2 Mk.

6 Skp. udi Heeland à $1 \mathrm{Mk} .8$ sk.

2 Bitræer, hel slette

1 gl. Egeskive

1 gl. Kornbing $\left.{ }^{1 "}\right)$

skorstenstøj

\% Td. med 2de sibotter

1 rlaglig seng

17 Mk. I. (yb:k)

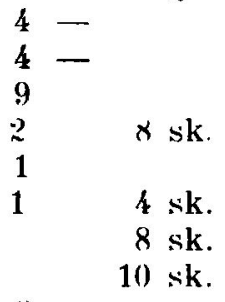

6

Summa 45 Mk. 14 sk

Boet kan vel nok med Rette betegnes som mringe«. Vurleringsmandene har antagelig ogsaa ved deres Ansattelse varet saa lempelige son vel muligt. Peder Horlyk har vel nok taget med sig, hvad der fandtes af Penge, og hvad der i en Fart kunde gores i Penge. Den ganle Mand, der næppe kunde gore sig Haab om selv at bjerge Folien, maatte jo have noget til Livets 
Ophold. - Det var dog ikke alle de 45 Mark, der tilfaldt Kongen eller Staten. Fra nævnte Sum "afgaar den halve Del, som er hans Hustrus Anpart, som er 22 Mk. 15 sk." Det er endog muligt, at Kongen har været saa naadig at lade hende beholde sin Part. Det skete i hvert Fald jævnlig. ${ }^{20}$ )

Men Karen Horlyk har vel gaaet med Forventning om, at den kongelige Naade skulde række endnu videre ud. Det var en kendt Sag, at Folk, som havde mistet deres Fred, kunde kube den tilbage igen hos Kongen, der da tildelte dem et Oprejsningseller Fredebrev. ${ }^{21}$ ) Først maatte der dog ske en Udsoning med den dræbtes Slægt, der havde Krav paa Erstatning Mandebod. At Peder Hørlyks Slægt har næret Tanker i den Retning, fremgaar af en lille Begivenhed, som fandt Sted hin 19. December lige efter Oplæsningen af Sandemændenes Tov. Da traadte Ebbe Jensen - sikkert en nær Slægtning, der handler paa Familien Hørlyks Vegne ${ }^{22}$ ) - frem paa Tinget, hvor han ikke blot begærer en Afskrift af "Dommen«, men han udtaler tillige, at han "skyder sig til Kongen og Hans højvise Raad at søge bedre Naade, og byder Bod og Bedring til den afdødes Frænder, og ellers erklærer ikke at have paa Sandemændenes Toug noget at appellere, men alene vil søge Naade. ${ }^{23}$ ) Man kan maaske lige som høre den gamle Sandemands Røst gennem Ordene: Han har ingen Bebrejdelser til sine gamle Kolleger. De maatte dømme saadan. Skal han redde sit Liv, maa han ty ind under kongelig Naade.

For nylig var der to Mænd fra Egnen med et Drab paa Samvittigheden, der havde faaet deres Fred hos Kongen, efter at de havde udsonet sig med den dræbtes Slægt. Den ene var Herredsfogden i Haderslev Herred, Nis Hansen Keding paa Olufskær i Starup Sogn. ${ }^{24}$ ) Han var kommen for Skade at dræbe Mikkel Sørensen fra Magstrup. Nu havde han ikke blot betalt den dræbtes Slægt den af Loven fastsatte Mandebod - tre Gange 18 Mark - men godvillig ydet en Overbod (Gørsum), hvorfor Slægten giver ham en "sikker og fri Orfejde" (Forsikring) med Tilsagn om, at der ikke i Fremtiden skal »ankes« paa ham i nogen Maade »for denne Vaadesag“. Det paalægges da -- i Juli 
1680 - Rigefogden at "lyse Kongens Fred« over Drabsmanden. Paa den Tid er Nis Hansen Keding Herredsfoged i Gram Herred i den midlertidig afsatte Peder Hansen Holms Sted. Da Peder Hørlyk paa samme Tid var Sandemand, kan der ingen 'Tvivl være om, at Karen Horlyk har kendt den Sag.

Rimeligt er det, at hun ogsaa har hort on Frederik Jørgensen paa Fuglsang i Oksenvad Sogn, der for en 25 Aar siden var »kommen.til Ulykke« og havde »ud af Vaade« drabt Hans Hansen i Orsted. I flere Aar var han "landflygtig“, men saa bliver han forligt med den dræbtes Slægt, der ligeledes giver ham "en fri og sikker Orfejde" med Tilsagn om, at Drabet "aldrig skal blive mere tænkt, hævnet eller angret paa Frederik Jorgensen eller nogen af sine enten med Ord eller (xerninger.« De skal herefter "leve med hverandre rolig, fredelig og vel uden alt Had og Fjendskab«. Og saa bliver han da i Foraaret $166 \%$ waf kongelig Naade .... perdoneret. ${ }^{25}$ )

Maaske Karen Hørlyk ogsaa har hørt om et Drab, der fandt Sted 1627 ovre paa Vestkysten. Præsten Hans Andersen i Skærbæk var da "geraadet i Slagsmaal " med Nabopræsten, Kristen Billum i Brøns og havde dræbt denne med en Pennekniv. Hans Hustru, Lene Ivers Datter, faar imidlertid "ved Tingsvidner og Sandemænds Tov« godtgjort, at det er Prasten i Brøns, som "forst har overfaldet og slaaet" hendes Mand, der har handlet i Nødværge. Kongen udsteder da 22. Juni 1630 et "Oprejsningsog Fredebrev« for Hans Andersen. Heri siges det, at Kongen har tilgivet ham hans Gerning, saa den "ikke nu skal komme ham til Hinder eller Skade i nogen Maade«. Og det tillades ham atter at søge Præstekald - dog uden for de jydske Stifter. ${ }^{26}$ )

Det kunde vel ikke siges, at Peder Hørlyk havde handlet i Nødværge, og det Drab, han havde gjort sig skyldig i, kunde heller næppe kaldes Vaadedrab. Alligevel har Karen Hørlyk sikkert nok til det sidste haabet paa en god Udgang paa Sagen. Hvordan gik det saa? Der forløber henved tre Aar, inden Peder Horlyks Navn atter nævnes i Tingbogen. Det er den 3. November $168 \%$. Herredsskriverens Beretning om, hvad der handte hin 
Dag, er desværre grumme kortfattet. Der er, siger han, sintet andet vorden forrettet end som de tvende Domme ... for begangen Manddrab er vorden for Retten« oplæst tilligemed »hans kongelige Majestæts allemaadigst derpaa givne Confirmation til Dommenes Execution«. Beretningen slutter med at udtale, at Dommene over "de tvende Fanger straxen (er) vorden exeqverit, og henrettede«. Den ene af de to Fanger er Peder Hørlyk, og det er rimeligvis i Haderslev, han sidder fangen. Vi faar intet at vide om, naar han er kommen i Fængsel, eller hvor han har levet $i$ den lange Tid, siden Drabet fandt Sted. Har han flakket om som landflygtig uden for Kongens Riger og Lande, eller har han vovet at drive om inden for Landets Grænser, selv om han derved forbrød sin Hals, om han blev paagreben? Der vär adskillige fredløse, der indlod sig paa dette Vovestykke. Baade Politi og Fæengsler var det sparsomt med paa den Tid. ${ }^{27}$ ) Men Rettens Arm har, som vi ser, nu faaet ham fat. Og nu maa han bode med Liv for Liv. For hans Vedkommende har der ikke været saadanne formildende Omstændigheder tilstede, at der kunde gives ham Del i Den kongelige Naade.

Paa Hammelev Mark lidt syd for Landevejen mellem Haderslev og Ribe ligger der en Høj, som bærer Navnet Loddenhøj - i en Mark af samme Navn. . Paa denne Høj skal de paa Gram Herreds Ting domfældtes Afstraffelse have fundet Sted. ${ }^{\circledR 8}$ ) Og her er Peder Hørlyk sikkert nok ogsaa henrettet. Antagelig er det den daværende Skarpretter eller Mestermand i Haderslev Christopher Soltwedel, der har foretaget Henrettelsen. En Skarpretter var foragtet af alle "ærlige« Mennesker, derfor var vel ogsaa hans Embede som Regel godt lønnet. I Haderslev havde han Fribolig med Have og Gaardsplads uden for Byen, en fast aarlig Løn af $40 \mathrm{Mk}$. 1 . og flere forskellige Sportler. Desuden fik han ekstra Betaling, hver Gang han var i Funktion. ${ }^{29}$ ) Han har sikkert ved forefaldende Lejligheder "praktiseret" ved Omegnens Rettersteder. On en af hans Forgængere, Mester Hans, hører vi saaledes, at han 1641 fra Riberhus Len faar udbetalt 40 Dlr., fordi han ved Lenets 4 Ting- 
steder har kagstroget 12 Kivinder, msom havde forset sig med Beliggelse. ${ }^{i 30}$ )

En Henrettelse kuncle foregaa paa flere Maaller. Mens Troldkvinden germe blev brandt, blev den, der var dnmt til Doden for 'Tyveri, hengt op i len (ialge, der som hegel fandtes ved hvert Rettersted. De fleste dodsdomte blev dog nok halshuggede - med svard eller Økse. Hængning betragtedes som den haardeste straf, og den forte Vanære med sig. Det blev derfor betragtet som en Naadesag, naar nogen fik Straffen forandret fra Hæugning til Halshugning. Antagelig er Peder Hørlyk blevet halshugget. Maaske har han ogsaa - som Skik var flere steder modtaget en styrkende eller bedøvende Drik, inden han blev halshugget."

I Danske Lov, ${ }^{\text {;") }}$ (ler gengiver tilsvarende Bestemmelser $\mathbf{i}$ len kongerigske og den slesvigske Kirkeordinans er det paalagt Præsterne ofte at besuge "Misdxdere, som for deres Misgerninger paa deres Liv sidde i Fangsel « og "undervise demmem til deres Syuders Vederkjendelse og Guds Naades 'Tilflugt«. Det paalagges dem tillige at folge de dodschonte til Retterstedet nog intet efterlate af den Undervisning og Iormaning, som dem til deres Salighed kan gives, og ej overgive dennenı, forend de blive henrettede«. Disse Lovbud er naturligvis ogsaa praktiserede over for Peder Horlyk vel nok af den Prast, i hvis Sogn han sad fæugslet. Vi kan dog ikke tvivle om, at den Mand, der tidligere havde været hans Sjælesorger, Matthias Schinck, som tilmed boede $\mathrm{i}$ Narheden javulig har besogt ham og maaske ogsaa fulgt ham til Retterstedet. Hvem ved, om ikke ogsaa Johan Degu har gastet ham og "tjent hannem i sit ydersteu.

Af de $\times$ Mand, der den I)ag var 'Tinghørere, var kun een fra Hammelev, de 7 antre val fra skryctstrup Sogı. En af le syv er Thomas Tjellesen, hall, hvis Bryllup hin Efteraarsdag for 3 Aar siden var endt som et Solgespil, der forte saa megen llykke med sig. Vi kan dristig gaa ud fra, at de 7 Mrnd ikke er de eneste fra Skrydstrup, der har overvoret Henrettelien. I Almindelighed modte lolk frem i tatte skarer baade gamle og unge - for at overvære en Henrettelse. Maaske de syv har 
været med til at slaa Kreds eller danne Ranme omkring det blodige skuespil, Det kunde nemlig knibe med at holde de nysgerrige Tilskuere $i$ tilbørlig Afstand..$^{33}$ ) Der var ogsaa nogen, der sogte at trange sig frem af mere praktiske Grunde. De vilde se at tilvende sig noget af den hemrettedes Blod, der mentes at vare et udmerket Lagemiddel mod Ligfald, engelsk Syge og anden Sot. Særlig eftertragtet var Blodet af en Morder. ${ }^{34}$ ) Den Omstændighed, at der var to, som skulde henrettes, har naturligvis ogsaa virket dragende. Den ene af dem var tilmed ikke nogen helt almindelig Forbryder. Han var jo en af Egnens kendte Skikkelser, For faa Aar siden var han optraalt paa Tinget som Dommer, ja enkelte Gange som Herredsfoged.

Da nu Henrettelsen havde fundet Sted, fik Familien vel Lov til at tage Peder Horlyks Lig med sig for at stede det til Hvile paa Hjemsognets Kirkegaard? Ønsket om at komme til at hvile i indviet Jord var brændende hos mangen dødsdømt saavel som hos hans Familie. Det har sikkert ogsaa været Tilfaldet her. Vi hørte, at Præsten ikke maatte forlade den dodsIømte, for Henrettelsen havde fundet Sted. Var den fuldbyrdet. saa var det ogsaa forbi med den præstelige Betjening. Præsten maa hedder det i Danske Lov 2-10-4 wej kaste Jord paa eller holde Ligprædiken over nogen, som for sin Misgerning er bleven rettet, eller har myrdit sig selv med v'ilje«. Hverken Selvmorderen eller den henrettede kunde gore Krav paa en „ærlig, kristen Begravelse«. Begge blev som Regel begravede paa Retterstedet eller i Narheden af dette. Ogsaa her gælder dog det gamle Ord, at der er ingen Regel uden Indtagelser. Selvmorderen kunde blive begravet paa Kirkegaarden, naar harr havde handlet "i Srgdom og Raseri«. Der findes ogsaa Eksempler paa, at der er sket (Indtagelser over for henrettede. ${ }^{35}$ ) Det mest sandsynlige er vel nok, at Peder Horlyk ligger og sover sin sidste Søvn i Loddenhøj derhenne paa Hammelev Mark.

\section{Pẹler Horlyks Hjemstavn og Slægt.}

Inden vi tager Afsked med Peder Horlyk, vil vi dvale lidt ved hans Hjem og hans slingt. I Tingbogen kuldes han snart. 
Peder Hansen, suart Peder Hørlyk. Det sidste Navn har han naturligvis fra stedet, hvor han boede. Nu om Dage er Hørlyk en By med en enkelt Gaard og 8 nindre Ejendomme i den nordvestlige Del af Skrydstrup Sogn. For en Del Aar siden var der to Gaarde her. De laa, fortæller gamle Folk, saa tæet op ad himanden, at de var fælles om en Lade. Saa var der ogsaa pt Kaadnersted, der laa ved Skellet mellem Skrydstrup og $\mathrm{Nu}$ strup Sogne. Man mener, at det i sin Tid er skilt ud fra en af de to Gaarde som et Aftagtssted. Det er maaske her, at Peder og Karen Hørlyk har haft deres Aftægtssæde.

Af Skatteregistre for Torning Len fra 1542 synes det at fremgaa. at der paa den 'Tid kun var een (iaard i Hørlyk. Den var beboet af Peter Negelsen eller Peter Nissen, som han ogsaa kaldes. Da den Skat, hall svarer til Kronen, er betydelig størle end den, der svares af Sognets andre Bonder, faar man Indtryk af, at Horlyk har været en storre Gaard. Samme Indtryk faar man ved en Sammenligning med Ydelserne fra andre Gaarde i Lenet. $^{\text {s6) }}$ )

Gennem en Fortegnelse over Tiendeydere i Ribe Stifts sønderjydske Herreder fra 1599 faar vi nogen Oplysning om Ejendomsforholdene i Skrydstrup Sogn paa den Tid, særlig over Gaarden Horlyk. ${ }^{37}$ ) Foruden Præstegaarden, der er tiendefri, er der 21 Gaarde i Sognet: 2 i Lilholt, 4 i Uldal, 14 i Skrydstrup og 1 i Hørlyk. Alle Bønderne er Tjenere under Haderslevhus ogsaa de 3 Selvejere: Forskellen mellem Selvejere og Fæstere er iøvrigt ikke ret stor. Manden paa Hørlyk var Fæster. Han bar Navnet Niels Hørlyk. Mens Sognets andre Bønder er inde under Markfællesskab, har han sin Jord for sig selv. Han whaver ikke hans Jord i Otting, men han haver en stor Plovs Avl, en Enstedgaard«, hedder det. De fleste Gaarte er delt mellem to Besiddere. Paa to af Selvejergaardene er der endog 3 Ejere. Niels Hørlyk troner derimod som ene Mand paa sognets største Gaard. I 1629 er der ogsaa een Mand paa Harlyk, Hans Nielsen. $\left.{ }^{38}\right) 1649$ sidder Niels Hansen som ene Mand paa Holyk. ${ }^{39}$ ) I 1672 er Gaarden derimod delt mellem to, Peter Hansen og Niels Hansen.") Det er muligt, at der har varet Slagtskabs- 
baand mellem de skiftende Besiddere fra 1542 til 1672 . Navnene før 1650 tyder i den Retning. Mere tvivlsomt stiller Sagen sig for Tiden mellem 1650 og 72."1) Derimod synes det at vare utvivisomt, at Efterkommere af Egteparret Peder og Karen Horlyk uafbrudt har siddet paa den vestre caard i Horlyk to Hundrede Aar frem i Tiden.

Foran har vi hort om en Svigerson og en Søn af Peder Horlyk, som begge var tilstede ved Thomas Thjellesens Bryllup Somnen kaldes snart Niels, snart Niels Persen og snart Niels Hørlyk. Det er aabenbart ham, der har overtaget Fædrenegaarden, da Forældrene kom paa $\Lambda$ ftægt. 1686 nævnes han som Sognefoged. En Bemærkning fra Begyndelsen af 1685 gor det sandsymligt, at han allerede da har været det. Ved Brylluppet sigte han at faa sin Fader bort fra Ølkanden. Da tet ikke lykkes, gaar han - ligesom Præsten hjem. Baade som Søn og som Sognefoged har han vel onsket at vare uden for den Leg, der nu var ved sin Begyndelse. - Endnu en Son var med ved Brylluppet. Han hed Laurs (Lavrids), og han havde en Gaard i Byen Gabol i Nustrup Sogn. Han blev af Rettell indstævnet som Vidne, men gav ikke Mode, han var "ront«. En Slægtning af den drebte vidner paa Tinget, at Laurs var uden Skyld. Antatagelig har heller ikke han onsket at vidne mod sin Fader.

Egteparret synes at have haft endnu en son boencle i Nustrup Sogn, Hans Persen Horlyk i Brundlund. Her havde han en Halvgaard i Fæste. Det, Tingbogen fortæller om ham, er ikke saa godt. Han synes som Faderen at have varet lovlig rask paa Haanden. I Foraaret 1683 er han kommen i sslagsmaal og Uenighed" med Peder Pedersen i Brundlund. Sidstnævite bliver saa medtaget, at han maa "under Badskærs (Lages) Haand" i Haderslev. Her bliver der ved Herredsfogdens og Ridefogdens Mellentkonst sluttet Forlig mellem de stri(dende $\left.{ }^{42}\right)$. Sagen bliver da "paa Højøvrigheds gode Behag saaledes modereret «: Hans Persen betaler Badskarlonnen, 3 Rillr., 6 Mk. l. i Erstatning til Modparten og-»kongelig Brøde" samt Gebyr til Øvrigheden. Begrundelsen for, at han slipper saa billigt, er betegnende for 'Tiden. Det er, for at skongelig Majestixts 
Fostegaard, som .... Hans Persen besad ...., ej skal staa ode, men(s) ved Magt blive.« Iet kneb med at skaffe Fæsitere til Gaardene. - Ret megen (ilade fik Øvrigheden dog nok ikke af den udviste Mildhed. Tre Aar senere horer vi om Hans Hørlyks "fast ode staaende halve Gaard" $\mathrm{i}$ Brundlund. I) forfalılıe Bygninger - 14 lag Salshus, (; lag Vesterlade og 5 lag Wsterlade vurderes til 31 Mk. 8 sk. - Naa, Hans Horlyk var ikke ene on at lobe fra sin Gaarl. Det horte nasten til Dagens Orden. Fra adskillige sogne hører vi om "fralobne«, ode Gaarde. Det er de forudgaaende Krige, der endnu kaster deres Skygge over Egnen: Lidt lysere er det dog blevet. Omkring 1670 hører vi om Byer, der er helt ode. Fra $16 t 39$ foreligger der en af flere Sognefogder underskreven Fortegnelse over Ejendomme, som er møllepligtige til Tørning Mølle. Af disse Ejendomme betegnes $52^{1 / 4}$ Gaarde som "gile og forarmede«. De fleste er kun saa forarmede, at cle har "fast intet at lade male«. Men en hel Del er ogsaa helt ode. l'arst ser det - ret naturligt ui i Eguen langs Harvejen. Vi navner for'st de to vestligste Byer i Hammelev Sogn. I Gammel Ladegaard er $5 \%$ Gaarde "ganske ocle«, i Jernhyt er 4 Gaarde "ganske afbrodte og ode«. Begge Gaardene i Lilholt, den ostligste By i Skrydstrup Sogn, er ogsaa "ganske ode og afbrødte«. Bedre ser det nok ikke ud i Nabobyen Over Jerstal i Vedsted Sogn. Her er $5^{\frac{1}{2}}$ Gaarde "ganske ude«. I Nabobyen Arnitlund er 5 Gaarde "ganske ode og afbrendte«, mens 2 Halvgaarde kun er forarmede. I Abkar er $21 / 2$ Gaarde ode.

Vi springer nu et Slagtled frem i Tiden. Gennem Kirkpbogen, der begynder 1710, og skyld- og Panteprotokollen, der begynder 1730, kan vi saa nogenlunde folge Beboerne paa de to Horlykgaarde. Paa clen vestre Gaard bor der fra Tiden omkring 1723 til 1766 en Mand ved Navn Peder Nielsen eller Peder Hørlyk. Han er uden lvivl Son af fornavnte Niels Persen og Søunesøn af Peder Horlyk. Ogsa han horer til Sognets og Egnens mere kendte Mand. 1730 bliver han Kirkeværge $\left.{ }^{43}\right)$, og lidt senere horer vi, at han er Sognefoged. De to stillinger sidder han indle med til sin Død, og vi hører da, at han - ligesom Bedstefaderen

\section{- ogsaa er Sandemand. I 1723 var han $23 \mathrm{Aar}^{\circ}$ ganmel}


bleven gift, og han har da rimeligvis overtaget (iaarden. Hustruen hed Johanna Christina, men vi faar desvarre ikke at vide, hvorfra hun stanmede. Gennem dem, der er Faddlere ved Børnenes Daab, faar vi et Indtryk af Familiens Omgangskreds. Der er Folk fra Nabogaarden og fra Sognets andre Gaarde, men en hel Del kommer fra Hjem, der er lidt udenfor Bondestanden. Ved de to forste Børns Daab er Bertel Simonsen, Skovrider i Hvidding og Nørre Rangstrup Herred, Fadder. Han dør 1731 antagelig i Skovriderboligen ved Lindet Skov i Højrup Sogn. Hans Hustru heder Dorthea Autzen. Det ligger nær at antage, at der har været Slægtskab mellem de to Familier i Lindet Skov og i Horlyk. I samme Retning tyder, at der hegge Steder er en Søn, som bærer det ret sjældne Navn Josias $\left.{ }^{44}\right)$. - Til de mere fornemme Faddere horer endvidere Herredsfoged Holm og Hustru, Torning, Forvalter, Sr. $\left.{ }^{45}\right)$ Karstensen og Hustru, Gram, Prastedatteren Jomfru Wedel fra Nustrup og Præstekonen fra Arrild. Lovise Slange, der ligesom Skovrideren optræder to Gange. Det er næsten en Selvfølge, at der ogsaa er hentet Faddere fra den hjemlige Præstegaard. Fra 1717 til 33 er Magister Iver Morup Præst i skrydstrup. Hans Hustru og Datter er begge Faddere. Da den gamle Præst er forflyttet til Nustrup, bliver den nye Præst, Thomas Wangs Hustru ret snart 1734 - antaget som Fadder. Præstens forste saavel som hans anden "Madame" er iøvrigt neget yndede som Faddere onkring i Sognet. Det samme galder i nogen Grad med Hensyn til Peder Nielsen.

Skrydstrup Kirke ejer endıu et synligt Minde om Peder Nielsen, ef saakaldet Ciborium eller en Sølvæske til Opbevaring af Alterbrød. Paa Laaget staar hans Navn og Aarstallet 1726. Da han endnu paa det Tidspunkt ikke var Kirkeværge, kan der ikke være Tvivl om, at det er en Gave fra ham til Kirken. - Paa en lille Salvkalk til Hjemmeberettelse fra 1736 staar Thomas Wangs og Peder Horlyks Navne. Indskriften betyder maaske, at Bægeret med tilsvarende Solvdisk er anskaffet i deres "Regeringstid«. Mere sandsynligt er det dog, at det er en Gave, de to har varet fælles om. I den Retning peger maaske 
ogsaa nogle Begivenheder fra Aarets forste Maaned. En Sondag midt i Januar begraves Peder Horlyks 5 Aar gamle Son rrederik. Den folgende Sondag begraves den 2 Aar gamle Josias. Faa Dage senere 27. Januar maa Prasten begrave sit eget Barn, der et Aar gammelt. "Min lille Datter Joamette« staar der i Dodsregistret. Man kan ligesom marke laderens Sorg gennem de faa Orl. Samme Aar dor den lille Piges Moler. Fwllesskabet i Sorgen har vist givet de to siml til at vare falles on Gaven. Det kan tilføjes, at Peder Nielsen gav sin første Gave det Aar, da hans Moder, malig Niels Horlokes« Hustru, Maren, døcle.

I Maj Maaned 1\%6t; afstaar Peder Horlyk sin Gaard til en Datter og Svigersøn. I) andre Børn har i Forvejen faaet deres Arvepart udbetalt. Nu overlader han de to unge Gaarlen med alt Tilbehør ude og inde sundtagen alle de Bitrarr, son han haver udstaaen til Halvt, og den halve Part af alle de Bistader, som staar hjenme ved Gaarden«. Desuden skal de unge udrede ¿00 Rdilr. Cour. i rerle Penge. Det skal vare som wen Haandskilling« til de gamle. Saa skal de enclelig nycle frit Ophold og Pleje paa Gaarden, saa lange de lever. Skulde det ske, at Forhollet mellem ganıle og unge i Gaarien ikke blev gorlt, skal ler opfares et 5 Fags Aftagtshus til de gamle $i$ mden vestre Kaalgaard«, og der skal da ydes dem en auseelig aarlig $\Lambda$ ftangt i Naturalier. Dette Hus er sikkert ikke blevet bygget. Peder Nielsen dør nemlig samme Sommer i en Aller af 65 Aar, og 3 Aar senere dor hans Hustru Johanna Christina ni hendes Allers 72\% Aar'. Paa sine gamle Dage navues Peder Horlyk flere Gange med Titlen Seigneur. Deme Titel betyder vel ikke sarlig meget, men den vianer dog om, at Perler Horlyk har indtaget en fremskudt Plads blandt sine standsfaller. Det ser nasten ud til, at han har varet slagtens Kronskud.

Hans svigersøn og Efterfølger hed Erich Bramsen. Han stanmede fra "Bierte" sikkert nok Sønder Bjart i Tyrstrup Herred. I hans 'Tid gik Gaarden - som saa mange andre nordslesvigske Ejendomme over fra larste til Selveje. 1795 afluses han af Somnen Christoffer Bramsen, ler liar Gaarlen til 1835. 
Saa efterfølges demne af sin San Erich Bramsen, der sidder med Gaarden til 1872. (Yemmem godt og vel 100 Aar havile samme Gaard saaledes varet i lamilien Bramsens Eje. Nu gaa* den gamle Slagtsgaard over paa fremmede Hander. Genmem lange Tider havle Stillingen som sognefoged fulgt (iaardens Indehaver.

Ogsaa den astre Gaar'd havile gemem lange 'Tider' varet i samme Slærgt: Eje. Til at begynde med gik den i Arv paa spindesiden. I Aaret 1765 var Hans Nielsen fra Or'sted i Oksenvad Sogn bleven gift med Datteren her, Maria Lauesclatter. Ved Peder Hørlyks Dorl det følgende Aar arver Erich Bramsen Stillingen som Sognefoged, Hans Nielsen derimod Stillingen som Sandemand. Gennem 4 slangtled skifter det med Hans Nielsen og Niels Hansen som Ejere af Gaarden indil 1883, da ogsaa denne Slægtsgaard kommer paa fremmede Hander. Saa lange Beboerne paa den vestre faard var en Hansen, Persen eller Nielsen, fik de som Regel stednavnet Horlyk knyttet til deres Fornavn. Familienavnet Bransen er jo saa sjaldent, at der næppe her var Anledıing til et sarligt Kendingsuavu. Efterhaanden glider saa Horlyknavuet over paa Ejerne af len ostre Gaard. Allerede i andet Slagtled begynder Beboerne her at dobe deres Born med Horlyk som Stamuavn.

I 1905 køber den preussiske Stat de to Horlykgarde og forener dem atter til en enkelt Ejendom, en Statsdomene paa (a. 140 Hektar. 1924 gaar Ejendommen atter over i privat Eje. De 64 Hektar forbliver verl Gaarden, og Resten udistykkes til Husmandsbrug.

Stednavnet Horlyk er i Tidens Lob skrevet ret forskelligt: Horlucke, Hørlyck, Høllech, Hòrløck, Hørløk, Hørlock, Hoerlòcke. Hørlyk, Hørlykke. Naar Navuet bruges som Persommavn, skrives det ogsaa ret forskelligt. Det har, sarlig i aldre Tid, veret ret udbredt. Ie fleste af dem, der har baaret Naviet, har vistnok arvet det fra Hurlyk i skrydstrup Sogn. I Xsby Sogn og i Horup Sogn og maaske flere steder - kendes ogsaa Hørlyk som Stednavn. Det er muligt, at nogen har deres Navn derfra. - Selv om det ikke kan siges, at alle de, der har baaret el- 
ler barer Naviet Horlyk, er i Slagt med den Peder Horlyk, der 1688 maatte lade sit Liv paa Retterstedet i Hanmelev, saa er det sikkert Tilfoldet med en I)el af (lem. Og saa er der naturligvis adskillige andre, der har noget af hans Blod i deres Aarer, selv on de ikke bærer hans Navn. Vi kan blot tæuke paa Navnet Bramsen.

\section{Brylluppet i Sonderballe.}

I det sydostlige Hjørne af Gram Herred og Hoptrup Sogn findes der en By ved Navn sunderballe. Den ligger idyllisk kønt i La af skov og hoje Bakker mod Vest med ldsigt mod Ost. over Lille Brelt og Gemmer l'jord. I den By indtraf der $i$ Aarene 1686 87 flere Begivenheder, som antagelig i nogen Grad har forstyrret Idyllen.

Søndag den 15. August 1686 holdes der Begravelse eller Begravelsesgilde i Sonderballe. To af de tilstedeværende Grster

Nis Boisen og Iver Hieronimussen - ypper Strid med hinanden. Sidstnævntes Fader, Hieronimus Simonsent6), moder den efterfulgende Lorlag paa Herredstinget med Klage over, at hans Søn "uformodendes (er) vor(len overfalden og udi Ansigtet med en Kniv saaret og beskadiget, som hverken kan skjules med Hat eller Haal«. Og han begarer, at Voldsmanden, navnte Nis Boisen, maa blive afstraffet efter Lovens Bud. Dell følgende Tingdag er Faderens Irede stilnet af. "Formedelst Godtfolks Intellemhaludling" er Parterne "vorden forligte". "Begge vil svare Fogdens og Skriverens Rettighed, enhver lige neget«. men Nis Boisen skal alene svare de "kongelige Broler". - Slig Legen med Kniv i Andenmands Ansigt var naturligvis ikke ufarlig, og det maa kaldes et Held, at Legen endte forholdsvis godt.

Værre gik det ved et Bryllup, der faa Maaneder senere -Tirsdag den 15. Oktober - holdtes i Sønderballe. Her er det to unge Mennesker, der om Aftenen kommer i strid med hinanden, og her ender det som ved Brylluppet i Skrydstrup Aaret forud med, at den ene med sin Kniv stikker den anden ihjel. 
Den drabte hed Iver Laursen, Drabsmanden Detlef Clausen. Demne betegnes som "Nis Persens Tjenestedreng«, og han var hjemmehorende i Tumby Sogn i Angel. Helt drengeagtig har Jan nappe været, siden han er kommen i Tjeneste saa langt fra Hjemmet.

Drabet fandt Sted i Kokkenet, og der var kun to Vidner til det, Merete Peders Datter og Bodel Hieronimuses, førnæunte IIieronimus Simonsens Hustru. Hun havde sin Plads »ved Skorstensilden" og har antagelig veret Koks ved Brylluppet. De to skulde egentlig have givet Mode paa Herredstinget og der aflagt Vidnesbyrd om, hvorledes Gerningen skete, men »eftersom de ej var saa stærke, at de selver til 'linge kunde erschinne og mode», blev det paalagt en Mand ved Navn Peder Hansen sammen med formante Nis Boisen at vare Mellemmand mellem dem og Retten. Kvinderne bekender "paa Sjæls og Saligheds Betragtning “, hvordan Sagen er gaaet for sig, og Mænrlene gengiver saa for Retten - efter forucl at have aflagt »deres højeste El « - hvad de to Kvinder har berettet. Boctel beretter da, at "liun sad ved skor'stensilden i Køkkenet, og Detlef Clausen, som gjorde (Gerningen, stod ved en Skive og karvede ${ }^{47}$ ) Tobak. Og talte da Detlf nogle schimpflige (skammelige) Ord til Bodil Hieronimusses og gik ned til hende med Kniven i Haanden. Imidlertid kom Iver Laursen ind til dennem, som sagde til Detlef: Hvad har du med den Kone at bestille, hun kunde baade vere min og diı Moder, det er en smuk gammel Kone. Og slog Iver tvende Gange efter I)etlef ned Haanden, Hen traffede hannem paa Hovedet ikkun den ene Gang. Stod saa Bodel Hieroninusses op og vilde gaa imellem til at forhindre, de ej skulde komme videre i Handelen. Des imidlertid slog Detlef til hammen med Kniven og bekom (Iver) sin skade og storte(de) straks død til Jor(len«. Merete samtykkede i Bodels Vidnesbyrd.

Seks Mænd fra Sonderballe viduede for Retten, at de liavde synet Liget af den drabte og fumlet, at han var sindstukken lned en Kniv 2 Fingers Bred over den venstre Patte ind ved den venstre side og ellers ingen andre saar paa hannem «. 
Forst er Peder Elberg, den drabbestes Morbroder, Eftermaalsmand, men da han kort 'Tin efter havde det theld "af Hojovrighed fangsigen (at blive) arresteret urli Haderslev" og saaledes ikke kunde bringe Sagen »til Endskab», maatte en Broder til (len drabte, Nis Laursen, overtage Hvervet. Den 27. November er Sagen naaet frem til Paakendelse af Sandemmolene. Af deres Toug eller Dom skal her anfsres det vigtigste: »Efterdi klarligen ses og erfares, at Detlef Clausen uden al billig Foje» har "drabt og hjertes]agen Iver Laursen og saa godt som skammeligen hannem sit Liv berovet" og samme D. C., "ller han sit oncle Forsat og slenme Vilje lavile fuldbragt, straks (er) bortgaaen og Sagen med sig tagen, og ikke siden hverken han eller nogen paa lians Vegne efter lovlig Citation (Stevning) .... til Tinge frenskikket for sig at svare, ... og ej let ringeste skriftlig Bevis og Dokument for os i Retten fremkom, hvorved kunde prasumeris (fornocles) D. C. at have varet foraarsaget til at gure Nodvarge og sit Liv at forsvare, eller og Vaadegjerning derved kunde eragtes«, saa ved de sej rettere .... at svarge og domme, end at D. C. efter Lovens (Jylske Lovs) 2. Bog, 12. Cap. jo haver dræebt sageslos Mand og er fordi (derfor) skyldig sin Fred at miste, og det saa sandt hjaelpe os Gud og hans hellige Ord."

Som Peder Horlyk var ogsaa Detlef Clausen straks rommet. Hvorlange hall har vandret onkring som fredløs, eller om lan nogensinde har faaet anden straf end Fredslosheden, derom giver Tingbogen os ikke mindste Besked, let var i hvert Fald - hvad man maaske kunde have tankt ikke ham, der sammen med Peder Hollyk henrettedes paa Herredstinget 1 ti\&8. Markeligt nok var vedkommende ogsaa fra sonderballe. Del var en 23-aarig ugift Kvinde, der ligeledes havde et Drab paa sin samvittighed, idet hun havde taget sit nyfolte Barns Liv. Hun hed Gjertrud Jebsclatter og var i Huset hos sin 63 Aar gamle Morbroder Jes Persen i Sxnderballe. En Gang tidligere havile hun raret frugtsommelig og folt et Barn. Denne Gang sagte hun læugst muligt at holle sin 'Tilstand skjult. Naar nogen af henles narmeste spurgte hende, om hum ikke var "trind eller 
"lavede til Barsel«, holdt hun dem hell med snak. Hun havde heller ikke sorget for Tøj til det Barı, hun skulde fode, eller for at der blev hentet Jordemoder ved Fodselen. Da Morbroderen kom ind til hende, efter at hun havde fodt, horte han, at "der var noget levendes ved hende, som smaapeb", og han sagde da: "Se dig for, hvad du gjør", men hun svarede: "I tør intet skjøde mig." (I behøver ikke at bryde jer om mig eller passe paa mig). Han henter saa paa hendes Bøn nogle Nabokoner. Da ie konmer, finder de et fuldbaaret Pigebarn liggende dod ved Moderens Side. Alt tydede paa, at hun selv havde taget sit Barus Liv.

Den 19. Maj 1688 er (ijertrud Jebsdatter til Vedermaalsting for at svare paa de mod hende rettede Beskyldninger. Hur begærer Ridefogden, at Herredsfogden skal afsige Dom i Sagen, og Herredsfogden lover, at Dommen skal blive afsagt "med allerforste." Denne Dom kendes ikke, vi ved kun, at Kongen stadfastede den, og at (ijertrud Jebsdatter blev henrettet 3. November 1688 sammen med Peder Holyk. Antagelig er huı "rettet med Sværdat" og Liget af hende begravet paa Retterstedet. Muligt er det, at hendes afhuggede Hoved er blevet anbragt paa Enden af ell opretstaaende Stage, en "Stejle andre til Skrak og Advarsel. Saadan skete det med to Barnemordersker fra Tonderegnen fyrretyve Aar senere. Og det ser ud til at have varet almindelig Skik paa den Tid at "stejle« de Modre, der havde taget deres Bams Liv."*)

\section{Efterskrift.}

Der klages $i$ aldre Tid starkt over de mange blodige Slagsmaal og Drab, der fandt sted. I en fỵrstelig Skrivelse fra 1617 klages saaledes over "de utallige, ja mangfoldige Mord", som fandt Sted paa den store $\emptyset$ Nordstrand. Faa Aar senere - 16i23 siger Prasten M. Boetius, der som faa kendte Forholdene paa Øell, at Folk her kunde myrde hverandre "ved en ringe, ja selv uden nogen som helst Anledning«. Og en lignende Kampiver vises ofte over for Landsmænd. "Næppe er", 
siger han, set eller andet Ord vekslet, for de med deres temmelig korte Knive genmemborer Brystet eller Sidernea paa dem, der er bleven Genstand for deres Vrede. Lignende Klager. horer vi fra andre Egne af Marsken." i al Almindelighed, og Klager har undertiden Hang til overdrivelse. Fra Brell Ribe har vi fra Aarene 1557 til 15titi mere

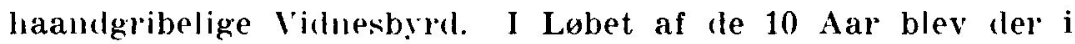
Byell drabt mindst 21 Personer eller gemmensuitlig : on Aaret. I samme Tidslum naatte 68 Personer bocle til Byen for saar, de havde tilfujet audre, 36 maatte bode for Slagsmaal og 3 for overlagt Overfald: ${ }^{: 01}$ )

Ved at lase det, der foran er fortalt fra Gran Herred, kan man maaske faa clet Indtryk, at Tilstanden der ikke var bedre heninod Slutuingen af det 17. Aarhundrede. Det var den dog nok. Ved at gennemgaa Herredets 'lingboger fra den 'Tid, faar man det Indtryk, at Slagsmaal vel forekommer hyppigt, men det er sjaldent, at de ender med Drab. Gennem 23 Aar fra 1667 til 1689 - navnes der i Tingbogen 5 Drab. De 4 Barnemorilet medregnet falder i de sidste 10 Aar. I de forudgaaende 13 Aar meldes der kun on eet Irab, der fandt Sted 16iz i Byen Orsted. Ved et Barselgilde her opstaar der Klammeri mellem to Ryttere. Det ender med, at den ene af dem dræber den

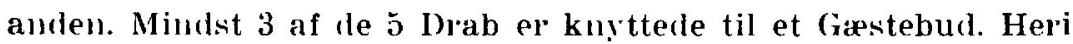
er dog intet underligt. De fleste Slagsmaal og Drab fandit sited ved selskabelige Sammenkomster, naar Hoverlerne var bleven ore af Drik. 


\section{Noter.}

1) For flere Aar siden har Hr. Landsarkivar Gribsvad og Hr. Pastor Carsten Petersen været saa venlige at henlede min Opmiærksomhed paa dette Bryllup. Forst nu har jeg faaet Lejlighed til at skrive om det. Hvor der ikke findes Kildeangivelse, er de af Gram Herreds l'inghager, der opbevares i I andsarkivet, Aabenraa, som Regel be. nyttede.

$\left.{ }^{2}\right)$ Personalhist. Tidsskr. 9, V, 135.

$\left.{ }^{3}\right)$ (). F. Arends Gejstligh. i slesvig og Holsten I 9, II 228.

: Her havde han og Peter Jessen i Fallesskab en Gaard. Haderslev Amits Jordebog 16\%2, Rigsark.

3. Det er vel nok Prastens egen og hans Hustrus, "salig Elsa Hr. llanses Begravelse«. De maa da være dode med kort Mellemrum. Hr. Mathias har lagt : $f i \mathrm{Rd}$. ud for hendes Begravelse. Dem har han tilgrode i Boet.

4) Troels Lund, Dagligt Liv i Norden i det 16. Aarh. XI $204 \mathrm{f}$.

5) Troels Lund, Anf. Skr. XI 265.

6) Det blev ikke til noget med Opsættelsen. Under Reparationen holdtes der Ting i Tørning Kro.

7) Kort over "den kongelige Avlsgaard" Tørnings Jorder 1774.

8) IIans Efterfølger var Sønnen Jacobus, der 1733 efterfølges af sin Søn Peder Christian, der dør 1779. Sidstnæunte er født 1706 paa (iaarden Solkjær i Grarup Sogn, som Faderen maa have haft paa den Tid. Han var den første Herredsfoged i Gram Herred med akademisk Uddannelse. IIammelev Sogns Kirkebog 1779, Archiv für Sippenforschung 1932, S. 339 f.

9) T. O. Achejis, Haderslev II 425.

10) De farste Kapitler i jyske Lovs II Bog handler om Sandemændene og deres Gerning.

11) Kofod Ancher, Saml. Skr. II 820.

12) Jfr. D. L. 1-16 - 2 og 3 .

13) Saml. t. jydsk IIist. ogr Top. I. $661 \mathrm{f}$.

19) Chr. Stemann. Schlesw. Recht u. Gerichtsverv, im siebenz. Jahrh. 158 Jydske SamI. I 448. Ved Retten i Gram ifaldt de Bøder, naar de udeblev ellor kom for sent. C. E. Andersen, Grams Hist. 189.

15) De hedder i Tiden omkring 1685 henholdsvis Martin Hansen og Christian Kornbeck.

$\left.{ }^{16}\right)$ Tye $=$ bevise. domme. Stemann, anf. Skr. 67.

17) Almindelig Betegnelse for den af Sandemændene afgivne Kendelse. Den kaldes ogsaa Dom eller Ed.

18) Hist. Tidsskr. 10, I, 395 f., Chr. Stemann, Den d. Retshist. 608 f. saaet.

19) Kornkiste, vel nok uden Korn, Rugen, der navnes, er sikkert

$\left.{ }^{20}\right)$ Hist. Tidsskr. 10, I, 439.

21) «Fredkøb" kaldtes den Sum, ler betaltes Kongen.

22) I Tingbogen noves flere Gange on Ehbe Jensen paa Gaarden 
Uldallund i Skrydstrup Sogn. Maaske har han været gift med en Datter af Peder Hørlyk.

${ }^{23}$ ) Teksten er noget medtaget. Den er her anfort efter stemanus Gengivelse i Schlesw. Recht u. Gerichtsverf. fra 1855, S. 181.

24) Ifolge et Gravmæele over ham og hans to Hustruer, der tidligere fandtes i Starup Kirke, synes han at vare dod 16\%). Danske Atlas VII 142.

25) Stemann, Anf. Skr. 17\%.

24) S. M. Gjellerup, Jens Dinesen Jersin, 17\%, Kancolliets Brevbøger 1630-32, S. 133, 148. Noget nyt Præsteembede fik han dog nok aldrig. Gennem mange Aar leverle han som Borger i Ribe. Fra Ribe Amt 1928, s. 67.

$\left.{ }^{27}\right)$ Hist. Tidsskr. 10, I, $433 \mathrm{f}$.

28) Trap, De sønderj. Landsdele, 151.

$\left.{ }^{29}\right)$ Achelis, Haderslev, II 364 f., 444 .

30) K. K. Kristensen, ()vtrup Sogn, 84.

s1) Hugo Matthiessen. Boddel og (ialgefugl, $4 \times$ f., 5\%. Kinch. Ribr: Bys Hist. II 667 .

32) $2-7-7$ og 8., H. F. Rurdam, Danske Kirkelove I 84-8., E. Michelsen, Die schl.-holst. Kirchenordn. von 1542 . II $60 \mathrm{f}$.

${ }^{33}$ ) Die Heimat 1929 , S. 90 f.

34) Hugo Matthiessen, Bodrlel og (ralgefugl, 95, Thiele, Danm. Folkesagn III 115, J. Brodersen, Fra gl. Dage, 97, 210.

35) D. L. 6-6-21, Aarb. for dansk Kulturhist. 1893 , s. $67 \mathrm{f}$.

36) Sonderj. Skatte- og Jordeboger fra Reformationstiden 86, 113.

37) Ribe Bispearkiv, Landsark., Viborg. Hr. Arkivar Ivittfoldt har varet saa venlig at henlede min opmarksonthed paa denne fortegnelse.

${ }^{38}$ ) Jordobog i Rigsurkivet.

39) Prasteindheretning om Tiencleydere, Gaarde og Bol, IRigsark.

a) Haderslev Amts Jordebog 1672. Rigsark.

41) I Tingbogen omtales der under 11/10. 1669 en sin Søn Peder Hørløck i Hørløck«. Er denne Jep Nissen maaske Stedfader til Peder og Niels Hansen? Trangselsaarene i Slutningen af Halvtredserne vendte op og ned paa Forholdene mange antlre Steder. Det har maaske ogsaa varet Tilfældet paa Hørlyk.

42) Medvirkende ved Forliget var en Broder Niels Porsen eller Niels Hørlyk - vel nok ovennæynte N. H. Iovrigt var der samtidig en Sognefoged N. H. i Skovby i Vedsted Sogn.

3) Kirkeregnskabshogen.

44) Personalh. Tidsskr. 1 R., 3 B, 114

45) Signeur, en fransk Titel, Herre. Bruges over for Folk, der haver sig lidt over det alm. Javnmaal.

46) Han var forhenvarende Gaardmand. Sidst paa Aaret 1683 havde han paa Grund af Pengevanskeligheder "med Ovrigheds Consens og Vilje" solgt Gaarden til Hans Pedersen fra Aarr. Han anholder om, at Køheren naf et kristeligt. Hjertelag vil lade sig finde og kjende at give hannem nogle smaa Stykker Land i hver Indtagt til sig. sin Hustru og Borns noxitorftigste og nogenlunde Ophold.« Det lader til, at Kaberen "af kristelig Affection" "resolverer" sig hertil - "saalaenge han (Hieronimus S.) og hans Hustru forholder sig skikkelig og vel imod hannem."

4) Skar Tobakshlade itu, maaske paa et "Karvebratu. Det faar staa hen, om det var til Gæsterne cller til sig selv, han skar Tohakken.

$\left.{ }^{8}\right)$ Die Heimat 1828, S. 67 f. I Jahrb. für die Landesk. der Herzogth. VI B. S. 95 Noten fortolles rer om en Barnemorilerske fra 
Sonderballe og en Tyv fla skrydstrup der samme Dag hængtes paa Gram Herreds Ting. Her er formentlig sket on Forveksling eller Fejlhuskning.

4y) Sønderj. Aarb. 19(k), S. $267 \mathrm{f}$.

so) Saml. til jydsk Hist. og Top. I $: 19 \mathrm{f}$. 